\title{
Nutrisi Efektif Mempercepat Penyembuhan Luka Perineum pada Ibu Post Partum (Systematic Review)
}

\section{Effective Nutrition Accelerates Perineum Wound Healing on Mother Post Partum (Systematic Review)}

\author{
Wellina BR. Sebayang ${ }^{1}$, Fitriana Ritonga ${ }^{2}$ \\ Prodi S1 Kebidanan, Universitas Imelda Medan, Indonesia
}

\section{ARTICLE INFO}

\section{Article history}

Received date

10 May 2021

Revised date

17 May 2021

Accepted date

31 May 2021

Keywords:

Effective nutrition;

Healing;

Perineal wound.

Kata kunci:

Nutrisi efektif;

Penyembuhan;

Luka perineum.

\author{
ABSTRACT/ ABSTRAK
}

\begin{abstract}
Accelerated healing of perineal suture wounds during the puerperium is expected to prevent postpartum mothers from the danger of infection. Several methods can be done to accelerate the perineal wound healing process, one of which is by adding a high protein intake. This birth canal wound can become a container for bacteria to enter so that it can cause infection, trauma to the perineum can cause discomfort and pain during sexual intercourse, therefore handling this perineal wound is important. Good nutrition according to several studies can accelerate the wound healing process perineum. The purpose of this study was to determine effective nutrition in accelerating the healing of perineal wounds in postpartum mothers so that it can be used as an alternative method for patients who give birth. This study uses a systematic review method by examining journal articles published through the google scholar site of the reviewed journals. There are 6 methods of effective nutrition to accelerate perineal wound healing, are fish cork extract capsules, zinc supplements, eggs, red guava juice, catfish, pineapple juice, and honey.
\end{abstract}

\begin{abstract}
Percepatan penyembuhan luka jahitan perineum pada masa nifas sangat diharapkan untuk menghindarkan ibu post-partum dari bahaya infeksi. Ada beberapa metode yang dapat dilakukan untuk mempercepat proses penyembuhan luka perineum salah satunya yaitu dengan cara penambahan asupan tinggi protein. Perlukaan jalan lahir ini dapat menjadi wadah masuknya bakteri sehingga dapat menyebabkan terjadinya infeksi, trauma pada perineum ini dapat menimbulkan rasa tidak nyaman dan nyeri saat melakukan hubungan seksual, karena itu penanganan luka perineum ini penting dilakukan Nutrisi yang baik menurut beberapa penelitian dapat mempercepat proses penyembuhan luka perineum. Tujuan penelitian ini untuk melihat nutrisi efektif dalam percepatan penyembuhan luka perineum pada ibu post-partum sehingga dapat dijadikan metode alternative pada pasien yang melahirkan. Penelitian ini menggunakan metode systematic review dengan menelaah dari artikel jurnal yang dipublikasi melalui google scholar dari jurnal yang ditelaah. Nutrisi efektif untuk mempercepat penyembuhan luka perineum ada 6 jenis yaitu dengan cara mengkonsumsi: kapsul ekstrak ikan gabus, suplemen zinc, telur, jus jambu biji merah, ikan lele, jus nanas dan madu.
\end{abstract}

Corresponding Author:

Welline BR. Sebayang

Universitas Imelda Medan Prodi S1 Kebidanan

Email: wellinasebayang@gmail.com

\section{PENDAHULUAN}

Hasil Survei Demografi dan Kesehatan Indonesia (SDKI) tahun 2012 menunjukkan peningkatan angka AKI yang sangat signifikan yaitu menjadi 359 kematian ibu per 100.000 kelahiran hidup. Berdasarkan hasil Survei Penduduk Antar Sensus (SUPAS) 2017 AKI kembali menunjukkan penurunan menjadi 305 kematian ibu per 100.000 kelahiran hidup. Salah satu penyebab kematian ibu adalah infeksi. Pada negara-negara berkembang paling sedikit satu 
dari sepuluh kematian ibu disebabkan oleh Infeksi. Luka post-partum masih menjadi kasus umum penyebab infeksi mencapai sebesar 8090\% (Budijanto 2019).

Infeksi nifas masih merupakan penyebab utama kematian ibu terutama di negara berkembang seperti Indonesia. 10\% kematian ibu terjadi pada masa nifas dan disebabkan oleh infeksi nifas akibat kurangnya perawatan luka, $42 \%$ terjadi akibat perdarahan, 13\% karena eklampsi dan $11 \%$ komplikasi nifas (Suyono, 2011). Luka perineum salah satu faktor predisposisi terjadinya infeksi masa nifas. Bentuk infeksi ini bervariasi dan bersifat lokal hingga mengakibatkan sepsis dan kematian masa nifas. Salah satu faktor resiko penyebab terjadinya infeksi perineum yaitu penyembuhan luka perineum yang lama. Penyembuhan luka jahitan perineum dalam masa nifas yang cepat sangat diharapkan menghindari ibu nifas dari bahaya infeksi serta keluhan fisiologis (Mochtar, 2013).

Penyebab terjadi luka perinium dapat disebabkan oleh 2 faktor yaitu faktor indikasi dari pihak ibu dan indikasi dari janin seperti bayi besar, makrosomia, distosia bahu, posisi abnormal, gawat janin. Banyak faktor yang memengaruhi penyembuhan luka perineum di antaranya dipengaruhi oleh pengetahuan, lingkungan, tradisi, sosial ekonomi, penanganan petugas, kondisi ibu, mobilisasi dini, vulva hygiene, luas luka, umur, vaskularisasi, stressor, dan juga nutrisi. Kebijakan program kunjungan selama antenatal care, kunjungan nifas, dan kunjungan neonatus bayi baru lahir adalah minimal 4 kali. Dengan standar minimal jadwal kunjungan ini diharapkan dapat mencegah dan medeteksi sedini mungkin masalah-masalah yang mungkin akan terjadi. Jadwal kunjungan masa nifas adalah 6-8 jam pertama post-partum, 6 hari pasca persalinan, 2 minggu dan 6 minggu pasa persalinan (Saifuddin, 2009).

Perineum adalah otot, kulit, dan jaringan yang ada diantara kelamin dan anus, luka perineum merupakan hal yang kerap terjadi pada saat persalinan. Luka perineum merupakan adanya robekan pada jalan rahim karena episotomi pada saat melahirkan janin. Robekan perineum terjadi secara spontan maupun robekan melalui tindakan episiotom. Robekan perineum terjadi pada hampir semua persalinan pertama dan tidak jarang juga terjadi pada persalinan berikutnya (Azizah, 2018).

Penyembuhan luka yang mengalami kelambatan di sebabkan karena beberapa masalah diantaranya perdarahan yang disertai dengan perubahan tanda tanda vital, infeksi seperti kulit kemerahan, demam dan timbul rasa nyeri, pecahnya luka jahitan sebagian atau seluruhnya akibat terjadinya trauma serta menonjolnya organ bagian dalam kearah luar akibat luka tidak segera menyatu dengan bai. Bentuk kesembuhan luka perineum yang baik adalah kesembuhan perprimer. Kesembuhan tersebut cirinya adalah tepi luka yang disatukan oleh jahitan menutup berhadapan, jaringan granulasi minimal dan jaringan paru tidak tampak.

Faktor yang memengaruhi kesembuhan luka perineum yaitu perawatan perineum, kualitas tidur, senam nifas, nutrisi, jenis material jahitan, tekhnik melakukan penjahitan dan pemilihan waktu melakukan penjahitan. Kandungan protein akan sangat memengaruhi proses penyembuhan luka perineum. Jaringan yang rusak membutuhkan protein tinggi untuk proses regenerasi sel baru. Peran protein sebagai zat untuk blok pembangunan otot, jaringan tubuh, tetapi tidak dapat disimpan oleh tubuh, maka untuk tahap penyembuhan luka dibutuhkan asupan protein setiap hari. Makanan dengan protein tinggi ini bisa didapat dari telur, baik telur ayam kampung, telur ayam ras maupun telur ayam broiler. Perlakuan yang paling baik pada telur yaitu dengan cara direbus sampai matang (Purnani, 2019).

Berdasarkan latar belakang diatas, maka perlu dilakukannya tinjauan systematic review yang mengidentifikasi berbagai metode percepatan penyembuhan luka perineum pada ibu nifas. Systematic review ini juga untuk melihat metode yang efektif untuk percepatan penyembuhan luka perineum sehingga dapat dijadikan metode alternatif penyembuhan luka perineum pada pasien di masa nifas.

Penelitian ini menggunakan metode systematic review. Sumber data penelitian ini berasal dari literatur yang diperoleh dari hasil penelitian (artikel penelitian) tentang penyembuhan luka perenium yang dipublikasikan di internet. Pencarian literatur dilakukan secara komputerisasi dengan data base elektronik google scholar. Kata kunci pencarian antara lain luka perineum, kapsul ekstrak ikan gabus, suplemen zinc, telur rebus, jus jambu biji, ikan lele, putih telur, jus nanas dan madu.

\section{PEMBAHASAN}

Strategi pencarian yang telah dilakukan dari berbagai jurnal penelitian, maka ditemukanlah jenis-jenis nutrisi efektif yang baik untuk dikonsumsi pada masa post-partum, untuk mempercepat proses penyembuhan luka perineum, yaitu: 


\section{Kapsul Ekstrak Ikan Gabus}

Kecepatan proses penyembuhan luka dipengaruhi oleh nutrisi yang dikonsumsi. Nutrisi yang dibutuhkan untuk mempercepat proses penyembuhan luka perineum akibat persalinan adalah dengan mengkonsumsi makanan yang tinggi serat dan protein. Protein banyak didapatkan pada makanan, khususnya daging dan ikan. Semua jenis ikan umumnya merupakan sumber protein yang sangat baik. Ikan gabus menurut berbagai sumber dan penelitian merupakan salah satu ikan dengan kandungan gizi dan protein yang lebih banyak dari ikan jenis lain. Ikan gabus cukup mudah ditemukan dengan harga terjangkau jika dibandingkan dengan beberapa jenis ikan lainnya, sehingga konsumsi ikan gabus dapat dijadikan sebagai salah satu jenis nutrisi mempercepat penyembuhan luka. Dengan memberikan ekstrak ikan gabus kepada kelompok perlakuan dimaksudkan untuk mempercepat penyembuhan luka perineum. Oleh karena ikan gabus merupakan salah satu jenis ikan dengan kandungan utamanya adalah protein atau albuminnya yang cukup tinggi. Umur yang cukup matang menyebabkan responden pada kelompok perlakuan yang mendapatkan ikan gabus mampu menyadari pentingnya untuk mengkonsumsi ikan gabus sebagai alternatif pengobatan dalam mempercepat penyembuhan luka perineum. Hal ini mempermudah kegiatan dalam proses kegiatan penelitian karena sikap responden yang sudah terbiasa mengkonsumsi ikan gabus sebelumnya.

Dalam penyembuhan luka perinieum dibagi menjadi dua kelompok yaitu kelompok Eksperimen dan kelompok kontrol. Pada kelompok eksperimen proses penyembuhan luka perinieum 7 hari penyembuhan artinya pada luka perineum sudah membaik dengan terbentuknya jaringan baru. Sedangkan pada kelompok kontrol proses penyembuhan luka pada hari ke-10, letak dari perbedaan kelompok tersebut yakni pada selisih waktu dari kedua kelompok perlakuan menunjukkan waktu pada kelompok eksperimen yang lebih cepat dibandingkan kelompok kontrol, karena adanya pengaruh ekstrak ikan gabus yang mengandung albumin dan mineral tinggi sehingga dapat mempercepat proses penyembuhan luka perineum. Terdapat perbedaan selisih 3,2 hari dalam proses penyembuhan luka antara kelompok intervensi dengan kelompok kontrol (Karina, Wagiyo, and Elisa, 2016).

Penelitian lain menunjukkan bahwa terdapat perbedaan kelompok intervensi yang mendapat ekstrak ikan gabus dengan mean 4,00 sedangkan kelompok kontrol mean 5,18, selisih mean 1,176 hal ini berarti bahwa kandungan albumin ikan gabus mempercepat proses penyembuhan luka perineum (Sari, Anggraini, and Putri 2020).

\section{Suplemen Zinc}

Zinc adalah mineral utama tubuh dan merupakan komponen pembentukan lebih dari 300 enzim yang dibutuhkan saat penyembuhan luka, menjaga proses kosepsi, fertilisasi dan proses pertumbuhan anak, sintesa protein. Zinc juga membantu reproduksi sel, menjaga penglihatan, merangsang imunitas dan mencegah radikal bebas. Zinc merupakan elemen utama esensial tubuh dalam menjaga kesehatan kulit dan mencegah terjadinya beberapa penyakit kulit tertentu. Suplemen zinc sudah banyak dipakai sebagai komponen utama untuk luka bakar, bintik merah karena diaper dan kondisi lesi lainnya (Almatsier, 2006).

Penyembuhan luka merupakan rangkaian proses perbaikan dari jejas di kulit atau jaringan lunak. Penyebab terjadinya luka bisa disebabkan oleh suatu trauma atau sayatan bedah. Hal lain seperti luka karena tekanan (biasa disebut luka dekubitus atau luka ditempat tidur) merupakan tipe ulkus kulit yang cenderung menjadi luka. Kemampuan cepat lambatnya kesembuhan suatu luka tergantung dari lokasi dan dalamnya luka dan sangat dipengaruhi status kesehatan dan nutrisi pasien. Proses yang terjadi segera setelah luka, terjadi proses inflamasi dan sel dibawah dermis atau lapisan kulit dalam akan memproduksi kolagen atau disebut juga dengan jaringan ikat. Selanjutnya akan diikuti oleh regenerasi sel epitel (lapisan kulit luar). Kombinasi antara diet dan nutrisi akan memperbaiki kualitas penyembuhan luka melalui proses tersebut diatas atau dengan menghambat kerusakan karena inflamasi (Smeltzer, 2002).

Penelitian ini dilakukan dengan metode quasi eksperimental, sampel dibagi menjadi dua kelompok yaitu kelompok eksperimen dan kelompok kontrol. Pada kelompok eksperimen waktu penyembuhan luka 5 hari yang diberikan suplemen zinc tablet $20 \mathrm{mg}$ 1kali/hari, sedangkan pada kelompok kontrol yang tidak diberi suplemen zinc selama 7 hari. Penyembuhan dari kedua kelompok terdapat selisih waktu 1,5 hari, dimana kelompok intervensi rata rata sembuh dalam 5,8 hari dan kelompok kontrol rata-rata sembuh dalam 7,3 hari. Kesimpulannya terdapat pengaruh konsumsi suplemen zinc terhadap waktu penyembuhan luka perineum. Suplemen 
zinc baik untuk dikonsumsi ibu pada masa postpartum karena sudah terbukti dapat mempercepat proses penyembuhan luka perineum. Hal ini diharapkan menjadi alternartif kebijakan yang diterpakan oleh tenaga kesehatan dalam memberikan asuhan kepada ibu nifas, sehingga dapat menurunkan angka kejadian infeksi pada masa nifas (Jamhariyah, 2019).

Penelitian lain menunjukkan bahwa ibu nifas yang mengkonsumsi zinc dosis tinggi lebih cepat sembuh dibandingkan ibu yang mengkonsumsi zinc dosis rendah, ibu yang mengkonsumsi zinc dosis rendah berpeluang 5 kali lebih lambat sembuh (Mahromi and Gustina, 2019).

\section{Telur}

Salah satu cara yang dapat dilakukan bagi pemulihan ibu post-partum adalah gagasan yang diperoleh dari dunia yaitu makanan hewani yaitu telur rebus. Telur adalah jenis lauk pauk protein hewani yang murah, mudah ditemukan, ekonomis dan salah satu makanan paling padat nutrisi. Telur jenis makanan yang sangat mudah diperoleh oleh masyarakat karena harganya yang cukup murah dan banyak dijual di pasar. Walaupun harganya murah nilai zat gizi yang terkandung dalam sebutir telur cukup tinggi dan sangat bermanfaat khusunya bagi proses pemulihan luka. Kandungan zat gizi ataupun nutrisi yang terkandung dalam sebutir telur rebus utuh mengandung lebih dari $90 \%$ kalsium zat besi. Satu butir telur mengandung 6gr protein berkualitas dan asam amino esensial. Pada kajian ini telur rebus dibuktikan dapat mempercepat penyembuhan luka jahitan perineum pada ibu pasca persalinan atau ibu post-partum. Proses yang efektif dalam penyembuhan lukaperineum dalam masa post-partum sangat diharapkan untuk menghindari ibu dari bahaya infeksi.

Kandungan nutrisi dalam putih telur sebutir telur menurut beberapa sumber penelitian telah teruji lebih baik dalam membantu proses penyembuhan luka. Hal ini disebabkan karena putih telur mengandung albumin, asam amino essensial yang lengkap dan tidak ada memilik kandungan lemak seperti yang terdapat pada kuning telur. Kandungan zat kolin dalam telur rebus berperan mengganti jaringan yang rusak dan membantu pembentukan jaringan baru Putih telur dapat dijangkau oleh semua lapisan masyrakat karena harga yang sangat ekonomi, mudah terjangkau dapat dibeli dimana saja. Ini menjadi salah satu alasan utama kenapa putih telur dapat dijadikan sebagai salah satu alternatif dalam membantu proses penyembuhan luka bila dibandingkan dengan membeli ekstrak albumin yang harganya cukup mahal dan prosesnya tidak semudah mendapatkan putih telur (Purnani 2019).

Penelitian Abdurrahman, et al. (2020) yang dilakukan pada ibu post-partum spontan dengan luka perineum derajat 2 di Praktek Mandiri Bidan Utin Mulia Kota Pontianak, menyatakan bahwa ada hubungan yang bermakna pada pemberian putih telur dengan penyembuhan luka perineum. Fenomena yang terjadi pada sebagian besar responden sebelumnya masih mengikuti kepercayaan tradisi yaitu tidak mengkonsumsi telur, udang dan ikan laut karena dipercaya akan mengakibatkan gatal dan luka jahitan lama kering (Abdurrahman, et al., 2020).

Penelitian Dewi (2019) menyimpulkan bahwa Pemberian telur ayam broiler mempunyai Pengaruh yang signifikan terhadap penyembuhan luka perineum pada ibu nifas. Pada penelitiannya responden berjumlah 30 orang, dibagi dalam dua kelompok, 15 orang untuk kelompok kontrol, dan 15 responden lagi sebagai kelompok intervensi yang diberikan 2 butir telur rebus setiap hari selama 7 hari. Hasil penelitian menunjukkan rata-rata kelompok kontrol sembuh dalam 10-12 hari, sedangkan kelompok intervensi sembuh dalam 5-6 hari. Saran bagi ibu post-partum ataupun ibu dalam pemulihan masa nifas untuk mengkonsumsi 2 butir telur ayam broiler setiap hari, karena sudah terbukti dapat mempercepat proses penyembuhan luka perineum (Dewi 2019).

Dalam penelitian lain diperoleh hasil bahwa ibu nifas yang mengkonsumsi telur rebus rata-rata sembuh dalam 4,1 hari sedangkan kelompok kontrol yang tidak diberi telur rebus sembuh dalam 5,5 hari (Trianingsih, Yenie, and S.P, 2019).

\section{Jus Jambu Biji Merah}

Jambu merah sekarang cukup dikenal dikalangan masyarakat sebagai anti oksidan karana kandungan vitamin $\mathrm{C}$ yang tinggi. Vitamin $C$ selain sebagai antioksidan juga sebagai penghasil kolagen. Manfaat dari kolagen bekerja dengan elastin untuk mendukung jaringan tubuh serta membantu kelenturan dan kekuatan elastisitas kulit. Beberapa hasil study menyatakan bahwa konsumsi rutin buah-buahan khususnya buah dengan kandungan Vitamin $\mathrm{C}$ yang tinggi, dapat meningkatkan kekebalan tubuh sehingga terhindar dari risiko infeksi. Vitamin C sangat penting dalam sistem imun dalam proses penyembuhan luka. Buah jambu biji mengandung vitamin C 3-6 kali lipat lebih tinggi dari jeruk. Jambu biji juga kaya serat yang larut dalam air. Dalam 100gr buah jambu segar mengandung $228 \mathrm{mg}$ vitamin C. Jambu merah tumbuh subur di 
daerah tropis seperti Indonesia dan banyak dijual di pasar tradisional dengan harga yang murah sehingga dapat dikonsumi oleh semua kelompok masyrakat (Rusdi, et al., 2018).

Jambu biji merah merupakan anti oksidan karena kandungan vitamin $\mathrm{C}$ nya yang tinggi. Kadar vitamin $\mathrm{C}$ juga bermanfaat dalam sistem imun sehingga dapat mencegah terjadinya infeksi. Vitamin $\mathrm{C}$ dalam buah jambu biji merah juga sudah banyak diakui oleh industri kosmetik sehingga banyak digunakan dalam jenis produk kecantikan karena manfaat kandungannya terhadap kulit. Dalam penelitian eksperimen case control pada 20 responden, dengan intervensi pemberian jus jambu merah setiap hari selama 10 hari. Selanjutnya dilakukan pemeriksaan luka perineum pada hari ke tiga dan hari ke tujuh. Hasil penelitian ditemukan $40 \%$ kelompok intervensi sembuh rata-rata kurang dari 7 hari, sedangkan kelompok kontrol sebanyak $90 \%$ sembuh rata-rata pada hari ke 7-10. Ada pengaruh yang signifikan konsumsi jus jambu merah terhadap penyembuhan luka perineum (Setyarini, 2017).

\section{Ikan Lele}

Ibu nifas yang mengalami robekan
perineum pada saat persalinan berisiko mengalami infeksi nifas. Salah satu faktor penyebab terjadinya infeksi nifas adalah adanya beberapa bakteri yang dapat menyebabkan infeksi pasca persalinan, daya tahan tubuh yang kurang, perawatan nifas yang kurang baik, kurang gizi/malnutrisi, anemia, hygiene yang kurang baik, serta kelelahan. Upaya yang dapat dilakukan tenaga kesehatan adalah dengan memberikan asuhan yang baik pada ibu dan bayi. Hal ini diharapkan dapat mencegah kejadian infeksi yang akan berakibat menjadi komplikasi lebih lanjut. Informasi penting yang harus diperhatikan yaitu kebersihan, nutrisi, dan perawatan pada luka perineum.

Protein berdasarkan sumber terbagi atas dua yaitu protein hewani dan protein nabati, beberapa literatur menyebutkan bahwa protein hewani lebih unggul dalam proses pembentukan jaringan baru pada penyembuhan luka. Dalam tiap 100 gram ikan lele mengandung kadar air $78,5 \mathrm{gr}$, kalori $90 \mathrm{gr}$, protein $18,7 \mathrm{gr}$, lemak $1,1 \mathrm{gr}$, Kalsium (Ca) 15gr, Phosphor (P) 260gr, Zat besi (Fe) 2gr, Natrium 150gr, Thiamin 0,10gr, Riboflavin 0,05gr, Niashin 2,0gr. Ikan lele merupakan jenis ikan yang banyak diminati oleh masyarakat, disamping harganya yang murah ikan lele juga memiliki rasa yang enak untuk dikonsumsi. Harga ikan lele dipasar rata-rata sekisar Rp. 10.000-an per kg. Kandungan zat gizi dalam ikan lele tidak kalah dengan jenis ikan mahal yang biasa disarankan untuk dikonsumsi dalam proses pemulihan.

Hasil penelitian Fadelika (2018) lama penyembuhan luka jahitan perineum dengan mengkonsumsi ikan lele pada ibu nifas sembuh dalam waktu kurang dari 4 hari yaitu sebanyak $80 \%$. Lama penyembuhan luka jahitan perineum tanpa konsumsi ikan lele pada ibu nifas sembuh dalam waktu lebih dari 4 hari sebanyak 73,33\%. Kesimpulan ditemukan adanya pengaruh konsumsi ikan lele terhadap lama penyembuhan luka jahitan perineum pada ibu nifas. Konsumsi ikan lele pada masa post-partum dapat dijadikan sebagai salah satu upaya dalam mempercepat proses penyembuhan luka perineum pada ibu nifas, sehingga proses pemulihan bisa berjalan lebih cepat (Fadelika, Rahayu, and Sendra, 2018).

\section{Jus Nanas dan Madu}

Buah nanas memiliki nama latin ananas cosmosus ini tumbuh subur di daerah beriklim tropis seperti Indonesia. Buah nanas berasal dari benua Eropa dan menyebar hingga ke penjuru dunia, termasuk Indonesia. Kandungan zat gizi yang terkandung dalam nanas dalam sebuah nanas dapat ditemukan kandungan fitokimia berupa bromelin yang berfungsi sebagai anti peradangan. Selain itu, kandungan lain yang terdapat dalam nanas adalah (vit $\mathrm{A}$, vit $\mathrm{C}$, vit $\mathrm{B} 1$, vit B6, mineral, antioksidan, serat, lemak, kalium, protein, sukrosa, kalsium, natrium, fosfor, pektin, karoten, magnesium, karbohidrat, tiamin, air (Swastika, 2014).

Madu bersifat anti bakteri, antiseptik menjaga luka, sehingga mempercepat proses penyembuhan luka bakar akibat tersiram air mendidih atau minyak panas (Suranto, 2012). Sifat antibakteri madu dapat membantu mengatasi infeksi pada perlukaan dan anti inflamasinya dapat mengurangi nyeri serta sirkulasi yang memengaruhi proses percepatan penyembuhan dalam merangsang pertumbuhan jaringan baru sehingga mempercepat penyembuhan luka dan mengurangi jaringan parut atau bekas luka pada kulit. Madu juga mengandung tinggi senyawa antioksidan dan antibiotik (antibakteria). Kandungan tersebut berperan baik dalam memperkuat daya tahan atau immunitas tubuh. Kandungan antibiotik juga dapat menurunkan angka kejadian infeksi pada ibu post-partum yang baru melahirkan, terutama bagi ibu yang melahirkan melalui operasi caesar. Madu baik untuk dikonsumsi setiap hari dengan cara diminum langsung atau ditambahakan dalam minuman seperti air, susu, jus, makanan atau minuman lainnya (Suranto, 2012). 
Madu bersifat anti bakteri, antiseptik menjaga luka, sehingga dapat mempercepat proses penyembuhan luka bakar akibat tersiram minyak panas atau air mendidih (Suranto, 2012). Sifat antibakteri madu membantu mengatasi infeksi pada perlukaan dan anti inflamasinya dapat mengurangi nyeri serta sirkulasi yang memengaruhi proses penyembuhan dalam merangsang pertumbuhan jaringan baru sehingga mempercepat penyembuhan luka dan mengurangi jaringan parut atau bekas luka pada kulit. Kandungan senyawa antioksidan dan antibiotik (antibakteria) dalam madu cukup tinggi, sehingga dapat memperkuat daya tahan tubuh. Madu yang bersifat sama dengan antibiotik juga dapat menurunkan kejadian infeksi pada ibu postpartum, khususnya ibu yang melahirkan dengan proses sectio caesarea. Cara mengkonsumsi madu dapat diminum setiap hari dengan cara langsung atau ditambahakan dalam minuman seperti air, susu, jus, makanan atau minuman lainnya.

Hasil penelitian di Surabaya menunjukan kelompok intervensi yang mendapat jus nanas dan madu, luka perineum post-partum sembuh sebesar $87,5 \%$ hanya sebagian kecil yang belum sembuh. Kelompok kontrol yang tidak diberikan jus nanas dan madu, ditemukan bahwa luka perineum belum sembuh sebesar 75\% (Jamila and Anwar, 2017).

\section{SIMPULAN}

Ditemukan 6 jenis nutrisi efektif yang baik dikonsumsi untuk mempercepat proses penyembuhan luka perineum akibat persalinan. Jenis nutrisi tersebut yaitu kapsul ekstrak ikan gabus, suplemen zinc, telur, jus jambu biji merah, ikan lele, jus nanas dan madu.

Diharapkan kepada petugas kesehatan khusunya bidan yang memberi pelayanan asuhan kebidanan baik di puskemas maupun di rumah sakit maupun praktek mandiri memberikan penyuluhan tentang nutrisi efektif yang baik dikonsumsi ibu post-partum, agar luka perineum cepat sehingga dapat mengurangi resiko infeksi pada masa nifas.

Nifas. Jurnal Kesehatan, 5(2): 94-99.

Jamila, F., \& Anwar, Y. Y. (2017). Pengaruh Pemberian Jus Nanas Dan Madu Terhadap Penyumbuhan Luka Perinum Pada Ibu Post Partum di BPM Ny. Arifin S, SST. Infokes, 7(02), 5-12.

Karina, Nini, Wagiyo, and Elisa. (2016). Efek Pemberian Ekstrak Ikan Gabus Terhadap Penyembuhan Luka Perineum Pada Ibu Post Partum Di Bpm Bonangrejo Demak. Karya Ilmiah STIKES Telogorejo Volume 5.

Mahromi, Wilda Gana, and Erni Gustina. (2019). "Hubungan Tingkat Konsumsi Suplemen Zink Dengan Penyembuhan Luka Perineum Pada Postpartum Di RSKIA PKU Muhammadiyah Kotagede Yogyakata. [Skripsi]. Yogyakarta: Fakultas Kesehatan Masyarakat, Universitas Ahmad Dahlan.

Mochtar, R. (2013). Sinopsis Obstetri Fisiologi Patologi, Jilid 1. Jakarta: EGC.

Purnani, Weni Tri. (2019). Perbedaan Efektivitas Pemberian Putih Telur Dan Ikan Gabus Terhadap Penyembuhan Luka Perineum Ibu Nifas. Journal of Public Health Research and Community Health Development, 2(2): 126.

Rusdi, P. H. N., Oenzil, F., \& Chundrayetti, E. (2018). Pengaruh Pemberian Jus Jambu Suplementasi Zinc Terhadap Waktu Penyembuhan Luka Perineum Pada Ibu 
Biji Merah (Psidium Guajava. L) Terhadap Kadar Hemoglobin dan Ferritin Serum Penderita Anemia Remaja Putri. Jurnal Kesehatan Andalas, 7(1), 74-79.

Saifuddin. (2009). Buku Acuan Nasional Pelayanan Kesehatan Maternal Neonatal. Jakarta: YBPSP.

Sari, S. M., Anggraini, A., \& Putri, R. D. (2020). Ekstrak ikan gabus terhadap luka perineum. Jurnal Medika Malahayati, 4(4).

Setyarini, D. I. (2017). Konsumsi Jus Jambu Biji Merah dan Penyembuhan Luka Perineum. Jurnal Keperawatan Terapan (e-Journal), 3(1), 7-12.
Smeltzer. (2002). Buku Ajar Keperawatan Medikal Bedah. Jakarta: EGC.

Suranto. (2012). Khasiat Dan Manfaat Madu Herbal. Jakarta: Agromedia Pustaka.

Suyono. (2011). Patologi Kebidanan. Yogyakarta: Penerbit Nuha Medika.

Swastika. (2014). Kitab Khasiat Buah Dan Sayur Tumpas Segala Penyakit. Yogyakarta: Shira Media.

Trianingsih, Indah, Helmi Yenie, and Santi Fadilah S.P. (2019). Pengaruh Telur Rebus Terhadap Percepatan Penyembuhan Luka Perineum Pada Ibu Nifas 1-7 Hari. Jurnal Ilmiah Keperawatan Sai Betik, 14(2), 215. 